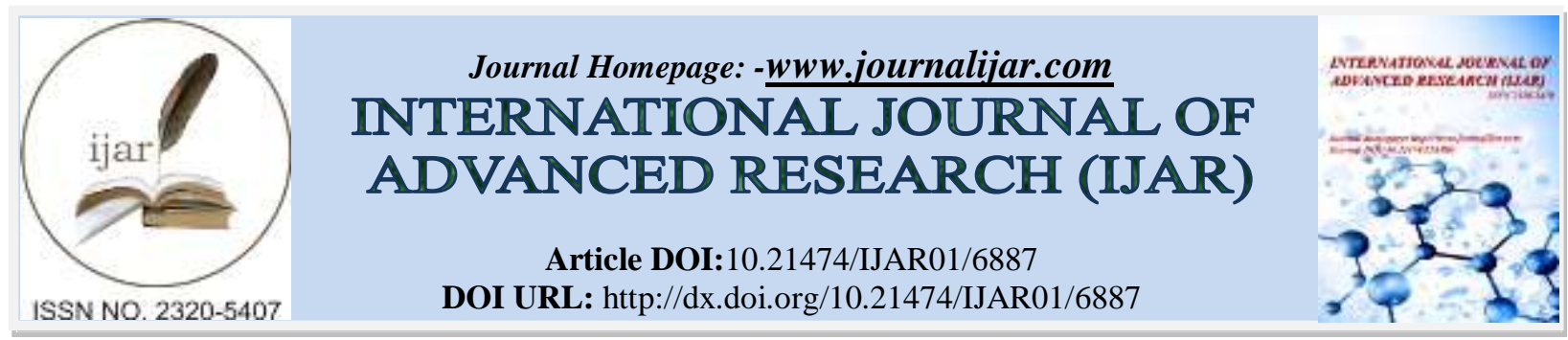

RESEARCH ARTICLE

\title{
LOCAL DECORATIVE VARIETY INNOVATION OF MANTINGAN AS A CREATIVE INDUSTRY DEVELOPMENT STRATEGY OF JEPARA CARVING ART.
}

\section{Eko Haryanto $^{1}$,Tjetjep Rohendi Rohidi ${ }^{1}$, Totok Sumaryanto Florentius ${ }^{1}$ and Dharsono Sony Kartika ${ }^{2}$.}

1. Fakultas Bahasa dan Seni, Universitas Negeri Semarang.

2. Institut seni Indonesia Surakarta.

\section{Manuscript Info}

Manuscript History

Received: 08 February 2018

Final Accepted: 10 March 2018

Published: April 2018

Keywords:-

Design, Handicraft, Local Decorative

Variety, Mantingan Jepara.

\section{Abstract}

The purpose of this research is to know the art of Jepara sculpture design which is currently experiencing design stalemate in Jepara and the process of inheriting the ability to carve on craftsman Jepara, innovate the art of carving through the application of decoration Mantingan to appear unique, quality and contemporary and produce a form of prototype 2-dimensional and prototype 3 dimensions of Jepara carving art that is unique, quality, and contemporary. This research design is designed by using Research and Development (R \& D) approach. Research location in Jepara. Research subject is carving art of Jepara. Research target is model of inheritance ability of carving art in Jepara, shape of quality of craft design and present design of carving of present moment of market demand, innovation model of ornamental art of Jepara carving, 2 dimensional and three dimensional prototype. Data collection methods used were observation, interview, documentation, and questionnaire. Data analysis used qualitative descriptive and quantitative statistical methods to analyze the literature study data and needs descriptions. The results showed the following. First, the design of Jepara carving art has been regional identity but less visualized in the style of contemporary and there is no craftsman who raises Mantingan style as an alternative new design in Jepara. The inheritance system of intergenerary carving ability is still done in familial patterns and informally, especially during the process of carving work in studio or production place. Second, the concept of innovation developed by researchers in order to produce unique, quality, and contemporary carvings through the use of ornamental subject matter Mantingan is vertical innovation, horizontal innovation, and geographical innovation. Thirdly, this research has produced 3 pieces of interior wall decoration design through the application of ornamentic and ornamental Islamic and figurative style disguised of Mantingan in the present style. The present impression arises because of the interwoven visual interplanation of Mantingan both internally and externally while still pursuing symbolic values as well as beautiful formalistic expressions and compositions. Suggestions that can be proposed are two-dimensional prototype and 3 dimensions need to be socialized to centers Jepara craft production so that its existence can improve the welfare of the community. 


\section{Introduction:-}

Jepara is known as a carving town because the furniture and handicraft industries are almost spread evenly throughout the district. But over the times, from 2008 the performance of Indonesian furniture exports, less aggressive with China, Tahiland, Vietnam, and Filiphina with creative innovation. Various creative industries in Jepara began to waver. As a result many producers are unable to survive and exist so that many craftsmen stop production, reduce workers, rent, disable or sell factories. It seems that various problems begin to emerge, from high skill individuality, finishing, informative marketing, and customer care, and unique product experience of quality degradation. Increased raw material quality that has begun to decline (Rusli, 2013).

In the case of Jepara sculpture, the authors assume that the low quality of handicraft design is more due to the artisans lacking creativity and innovation in development. Craftsmen often have only a single perception that Jepara's local ornament in general only has a mainstream style characterized by tendrils of plants and birds in a naturalistic and stylized style. Whereas Koswara (1996: 134) stated that the wealth of local Jepara ornaments attached to the wall carvings Mantingan Jepara mosque is very varied. The motifs include mountains, geometric, tree, arrow, flower, and ape with typical Jepara expression. If the motifs outside the mainstream are processed with a variety of styles of distortion, deformation, and transformation supported by thin concave engraving techniques and filigree it will produce a design that overwhelming abundant patterns.

Even to pursue global market markets, they are often trapped to adopt or inspire from Western handicraft designs. Although the crafters apply decorations from other regions of the archipelago, they do not understand the clear vision. They are not optimizing the wealth of decorative variety of Jepara culture itself. Local ornaments lack the courage to be explored again by artisans on the grounds of fear of loss of identity value. Apparently, Jepara decorative variety as the substance of locality is more positioned as a sacred object resulting in reluctance or fear to change it.

Design style that tends to stagnate from year to year resulted in the craft seem monotonous, static, rigid, and less dynamic. Though the demands of design style develop very fast and easy to change. A motto in the creative industry now new design no busssines to really hit the creative craft industry in Jepara. In this case, local decoration, especially decoration Mantingan less bold explored by crafters. The reason is the idea, imagination, and the idea of craftsmen still tend to be linear that is always producing by copying the existing design repeatedly. No new innovations to existing products. Though if a product will be worth high sales if it has a very artistic and aesthetic design so that someone becomes more impressed and interested in the design. Functional factors even become secondary (Sachari, 2005).

In that context, it seems necessary to develop a handicraft in Jepara through the revitalization of local distinctive decoration, especially Mantingan Mosque variety. Decorative Style Mantingan as local text in this sense is a motive or decoration that belongs to the identity of Jepara, especially that has not been applied to the art of Jepara carving. Whereas the texts, if used as subject matter in Jepara sculpture through the re-arrangement of Mantingan Mosque ornaments in new compositions or interrelated their existence with various other decorations both traditional and modern, so there is mixing of genres, generation or context then the stunt of carving art design will have a solution. Mantingan mosque ornament which is a traditional or local period style that needs to be mixed with decoration that again ngetrend in order to produce freshness in the design and harmonious of the era with still characterize the localization.

Based on the principle step, the research that will be done is to study the local decoration and traditional handicraft, to mapping the customer needs to the desired craft. With the mapping, the research continued the development of Jepara sculpture in order to be more qualified and aligned era so that the resulting prototype-craft prototype that is actually based on more dynamic local ornaments. The findings are then tested more broadly in order to obtain improvements. The results of this study is expected to support the creative industries in order to benefit the welfare of craftsmen and sellers in Jepara. Therefore, a unique and highly prospective design potential needs to be immediately actualized both in the form of a 2 dimensional and 3 dimensional prototype. The problem lies in: (1) Jepara sculpture ornaments generally experience stagnation in sales so that it needs an understanding of the inheritance system of Jepara carving skills, especially in the field of decorative development, (2) there has been no activity focused on optimization program of decorative potencies Mantingan as subject matter of ornamental carving 
art, and (3) it is necessary to make two-dimensional prototype and three dimension of ornamental carving to give an idea of ornamental art form which utilize decoration of Mantingan as an effort to solve the solution to the problem.

\section{Literature Review:-}

Literature study conducted by the writer to know the concept of beauty of the present and the decorative variety of Mantingan Jepara. The beauty of the present is based on Sumartono (2000: 22) that the beauty gained by to continue the forms from the style of tradition and modern style to the more recent direction. The decoration in Mantingan mosque has Islamic or Arabic, Chinese and Hindu style combined in a very interesting and unique style. First, decorative patterned Islamic characterized by the geometric decoration of interweaving and calligraphy. This motif according to Muslims is known Arabic motif. Second, the decoration with the motifs of plants including natural scenery and figurative motifs such as animals seem to dominate. Plant motifs such as vines (watermelon, passion fruit, and water gourd) and lotus or lotus motifs. Motifs of natural landscape such as hills, mountains, coral hills, gates, houses and their environment. The figurative motifs depict such a figure as even human, poultry, bats, horses, antelope, apes, crabs, and elephants. Bird motifs if identified have similarities with parrots, peacocks, and imaginative birds of the phoenix. While smaller birds are the type of emprit and gelatik. The uniqueness of the figurative form is the very successful disguise done well as a way or solution to avoid the ban on living things and considered as a strategy of Islamic spreading adaptation at that time.

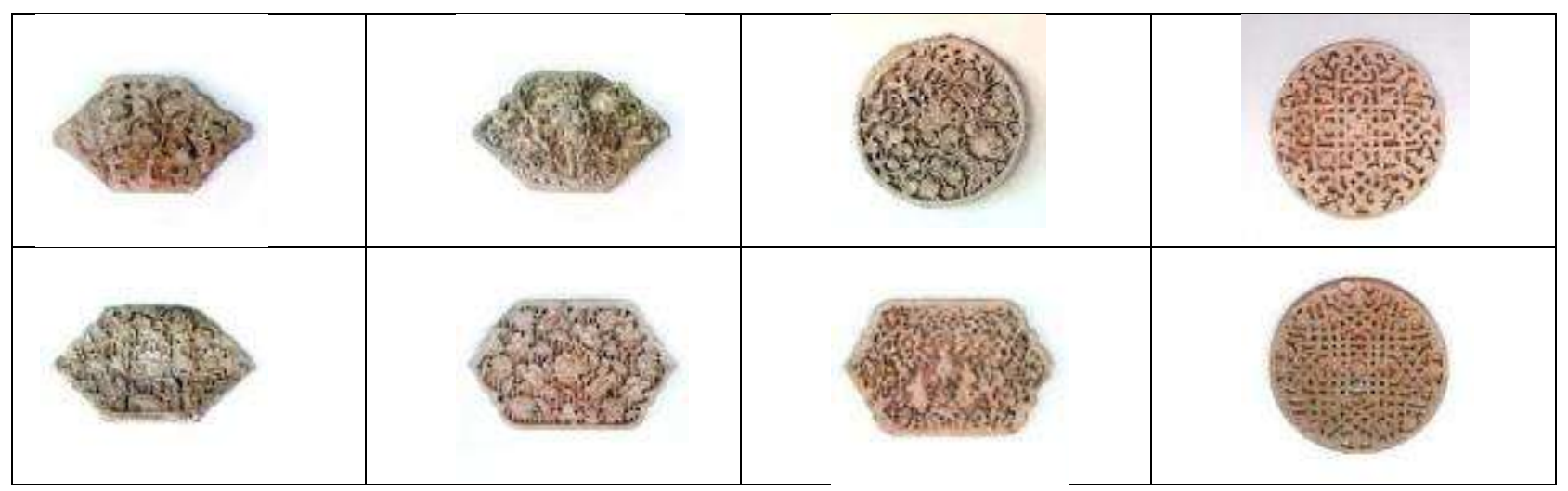

Fig.1:-Several samples of Mantingan Jepara Decoration varieties

\section{The Condition of Craft Design in Jepara:-}

Today, more products are predominantly carved than minimalist. It proves that carving craft is the spearhead of handicraft selling level in general in Jepara. Carving has a theme of animals, trees, fruits, flowers, animals, land, air, water, and tools of everyday utensils. The minimalist style only plays as a mere carrying capacity. The orientation of both local and foreign buyers is still on the craft of carving because it still has an expression aura. No one has tried to explore Mantingan Jepara mosque as a subject matter in the work of handicrafts that it produces. The indigenous motif approach is still limited to the tendrils.

\section{Description of Handicraft Needs:-}

The diversified demands of the desired product is a new craft design engraved by optimizing the potential of the locality but was able to stylish contemporary. In that context, what happens is that the craftsmen never use Mantingan mosque as a source of inspiration because of the inability to uncover the exploration of local wisdom ideas either at the level of paradigm or form ideas.

\section{Inheritance Process of Carving Art Craft in Jepara:-}

In general, the inheritance of the ability to engrave is a process of culturing knowledge, values, and cultural skills that are meaningful for future generations to be sustained and maintained in the future. The goal is to equip the skill in making woodcarving art to crafters as working capital to fulfill family economic needs and art of wood carving as cultural heritage must be protected, maintained and continued by the next generation in the future.

Inheritance system of inter-generational engraving capability is still done in familial patterns and informally, especially during the process of carving work in studio or production place through nyantric process (learning while working) and the environment. The majority of the community of craftsmen in Jepara carving used to carve out self- 
taught or those who carve out from generation to generation because of environmental or cultural factors that flourish in the community. The methods used in the process of carving art education in Jepara are demonstrations, modeling and internalization.

Development of HandicraftsArtworks through the Development of the Decorative Variety of Mantingan towards the Presence

\section{Pre-Design Phase: Concept Setting:-}

Based on the above reference, the exploration of this design is to modify the decoration of Mantingan in order to style with the concept of innovation concept of vertical innovation, horizontal innovation and geographical innovation. The concept of horizontal innovation is preferred for a carving product can be created in products both functional and decorative in a high degree of variant. Horizontal diversification can be broadly classified into three carved art products namely functional carving objects, aesthetic decorative objects, and symbolic objects either on functional objects or decorative objects. The concept of vertical innovation is product development by increasing the value of quality over quantity. Quality is defined in a product is the quality of the form, the quality of the technique, the quality of the material and the quality of the presentation. Geographical innovation combines more ornament Mantingan with various motifs Nusantara and international motifs. The author uses the concept of flexibility in designing the creation process is always dialectical in bringing together the value of locality with the values of the present with not trapped in the position of modern and traditional aesthetics.

\section{Research Methodology;-}

This research design used Research and Development (R \& D) approach. The research location is focused in Jepara especially in Mantingan mosque, production center and carving sales in Jepara. The subject of this research is decorative mantingan Jepara and wall hangings as carved craft products. This research stage covers the introduction and development phase. The preliminary stage includes literature studies and needs surveys. Data collection techniques using observation, interviews, and questionnaires and focus on group discussions. Inductive data analysis is done by collecting data as much as possible in field level, then done reducing, and drawing interactive conclusions and cycles. The development stage in this first year is a step of creation, engineering, exploration of the designs of contemporary wall decorations in three steps. Stages begin pre-design, design, and post-design to produce 2dimensional prototypes and 3-dimensional prototypes that in the process involve Product Evaluation from Experts User Interviews, Stakeholder Interviews.

\section{Findings and Discussion;- \\ Overview of the Jepara City:-}

Jepara regency is one of regencies in Central Java province. The total area of Jepara Regency is 27,263 KM². The potential of this natural environment condition causes Jepara to grow not only as an agrarian city but also as an industrial city. Even in its development, growth as an industrial city (craft carving-furniture) grow very rapidly even become a mainstay in the field of economy Jepara society. Until now, Jepara city is one of the central cities of woodcarving and furniture industry center in Indonesia. In fact, the quality of its industrial products is well known in foreign countries. Furniture industry is the most important commodity besides weaving troso, convection, ceramic/pottery. Potential and development of furniture industry in Jepara Regency is the most prominent in the Tahunan Area, which is shown by the existence of 32 large industries, 196 medium industries and 1.973 small industries scattered throughout the village. The birth process of Jepara as a carving town has passed the historical period starting at the time of the first Islamic cradle in Demak. At that time, Jepara has been used as a northern port in addition to the trade center and bases fleet of war so many immigrants from China. Second, the role of Queen Kalinyamat is very big in developing Jepara carving with evidence of traces of stone carving ornaments in Mantingan Mosque. And, last is the role of Raden Ajeng Kartini really very big in promoting Jepara carving abroad (Gustami, 2000). Furthermore, the era of education today in Jepara is supported by the instituion of an educational institution that is STM Negeri Majoring Carving Decoration which in the next to be Secondary School of Craft Industry Affairs (SMIK)

Aspects of horizontal product innovation with the creation of designs designed by researchers to function as a pure ornament for home or office interiors. Innovation is done through the use of Mantingan decoration variety on wall decoration through changes in scale of carving from the original small size to a larger size that will produce the impression of magnificent and strong and authoritative expression. 


\section{Stage of Design Process:-}

Exploration of Arabic Geographic Design Innovation:-

This design uses Mantingan motifs combined with batik motifs. Mantingan motif representing the icon of the past because it has never appeared in popular design combined with batik motif will produce a unique composition, fresh and new. The researcher's strategy is to decontextualize the meaning of Mantingan motif and batik motif itself. Retrieval of motif Mantingan and Motif Batik with the model taken from the original structure and then restructured in the new form will certainly offer a new aesthetic experience.

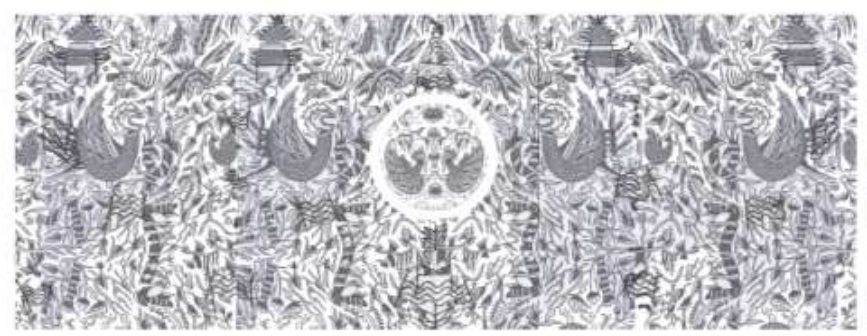

Fig.2:-Mantingan Motif combined Garuda batik motif with symmetrical composition to give the impression of dashing authoritative

Exploration of Arabic Horizontal Innovation Design Central Brown Coffe:-
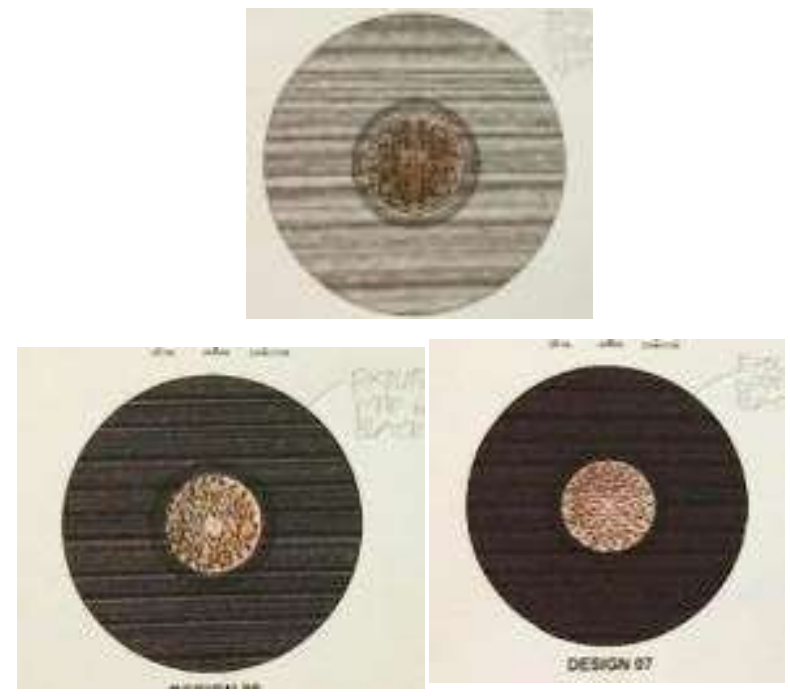

Picture 3:-Mantingan Motif is produced into wall decoration through the addition of a wide circle field so that the more contemporary image

Aspects of horizontal product innovation with the creation of designs designed by researchers to function as a pure ornament for home or office interiors. Innovation is done through the use of Mantingan decoration variety on wall decoration through changes in scale of carving from the original small size to a larger size that will produce the impression of magnificent and strong and authoritative expression.

\section{Exploration of Vertical Innovation Design:-}

Exploration of vertical innovation conducted by researchers is by product development through improving the quality of shapes, techniques, materials and presentation. In this case, the researcher focuses on the development of products that have excess product form, especially the beautiful shape, express something, and implies a local cultural values and ease during the production process. 


\section{Post-Design Stages:-}

To facilitate the embodiment of the best sketches that have been selected, it is necessary to draw the work by calculating the size through a certain scale and visualizing the front, side, and top. Next is the process of concretizing two-dimensional craftwork into three dimensions. Three-dimensional product that successfully realized is two pieces of interior decoration in the form of a circle of teak measuring $80 \mathrm{~cm} \mathrm{x} 80 \mathrm{~cm}$ with the middle part there is a patterned carvings of Mantingan decorative variety.

The process of making sculpture by using Mantingan ornament includes step material insipan, making design, engraving, and final settlement. The process begins with the selection of teak wood as carving materials and tools ranging from chisels, saws, and aids in the form of hammers (gandhen), pencils, and stones .. The process of moving the design from two dimensional design to the wood is done by enlarged design through photocopy so that it is $1: 1$ with teak plank field. The result of the photocopy is then attached with glue on the surface of the wood.

The process of making Mantingan interior decoration carving consists of several steps. The first step is to create the archetype that is the field of teak that will be formed to be carved by reducing the unneeded parts of the wood. Continued "nggetaki" process is to sculpt the image boundaries adjust the design patterns. The next step is to create a carving base, which is to create a global shape by determining deep or thick carving and engraving as a whole first, but the stages of engraving are still simple. Forming the carving pattern is done by adjusting the characteristics of each motif, which is making the surface of the wood surface and forming the surface of the wood to form a desired carving motif. The third step is "nggrabahi" which means to form the image or motif carving although still rough, the form has revealed the variety of hiasnya so that it can begin to be seen in the whole motifs that actualized or materialized though not yet smooth and detail. The next step, "matuti" to smooth the shape of the carving motif that is still rough and gives isen-isen on the engraving. In this stage, the engraver makes the shape as detailed as possible, so that the leaves bones, leaf curves, and geometric ornaments are clearly visible. The final step is the final settlement that aims to make Mantingan interior decoration become more beautiful, interesting, and admirable.

\section{Stage of Trial:-}

Small-scale trials are aimed at improving the three-dimensional prototype, especially the formal characteristics of the formal shapes, after small-scale trials the prototype is revised to be tested to a wider level. Because using the test, the prototype is made smaller than its ideal size. The quality indicators of craft art products are production efficiency and design, local identity identity, innovation and market potential, and final appearance. This small scale is done on several carving craft galleries in Jepara involving a number of respondents. Respondents are gallery owners, customers who are visitors in the gallery, as well as input from experts of wood art crafts. The author uses a carved diameter of $40 \mathrm{~cm}$ without using a circular frame that has a side width of the outer $20 \mathrm{~cm}$ engraved plane. Because of the artwork, the approach used to know the advantages and disadvantages of the work. To know the quality of design Whether the carving is in accordance with predetermined criteria, the authors use a questionnaire that is distributed to customers who are more of a tentative and supportive reading.

\section{Exploration of Vertical Innovation Design:-}

Exploration of vertical innovation conducted by researchers is by product development through improving the quality of shapes, techniques, materials and presentation. In this case, the researcher focuses on the development of products that have excess product form, especially the beautiful shape, express something, and implies a local cultural values and ease during the production process.

\section{Post-Design Stages:-}

To facilitate the embodiment of the best sketches that have been selected, it is necessary to draw the work by calculating the size through a certain scale and visualizing the front, side, and top. Next is the process of concretizing two-dimensional craftwork into three dimensions. Three-dimensional product that successfully realized is two pieces of interior decoration in the form of a circle of teak measuring $80 \mathrm{~cm} \mathrm{x} 80 \mathrm{~cm}$ with the middle part there is a patterned carvings of Mantingan decorative variety.

The process of making sculpture by using Mantingan ornament includes step material insipan, making design, engraving, and final settlement. The process begins with the selection of teak wood as carving materials and tools ranging from chisels, saws, and aids in the form of hammers (gandhen), pencils, and stones .. The process of moving the design from two dimensional design to the wood is done by enlarged design through photocopy so that it is $1: 1$ with teak plank field. The result of the photocopy is then attached with glue on the surface of the wood. 
The process of making Mantingan interior decoration carving consists of several steps. The first step is to create the archetype that is the field of teak that will be formed to be carved by reducing the unneeded parts of the wood. Continued "nggetaki" process is to sculpt the image boundaries adjust the design patterns. The next step is to create a carving base, which is to create a global shape by determining deep or thick carving and engraving as a whole first, but the stages of engraving are still simple. Forming the carving pattern is done by adjusting the characteristics of each motif, which is making the surface of the wood surface and forming the surface of the wood to form a desired carving motif. The third step is "nggrabahi" which means to form the image or motif carving although still rough, the form has revealed the variety of hiasnya so that it can begin to be seen in the whole motifs that actualized or materialized though not yet smooth and detail. The next step, "matuti" to smooth the shape of the carving motif that is still rough and gives isen-isen on the engraving. In this stage, the engraver makes the shape as detailed as possible, so that the leaves bones, leaf curves, and geometric ornaments are clearly visible. The final step is the final settlement that aims to make Mantingan interior decoration become more beautiful, interesting, and admirable.

\section{Stage of Trial:-}

Small-scale trials are aimed at improving the three-dimensional prototype, especially the formal characteristics of the formal shapes, after small-scale trials the prototype is revised to be tested to a wider level. Because using the test, the prototype is made smaller than its ideal size. The quality indicators of craft art products are production efficiency and design, local identity identity, innovation and market potential, and final appearance. This small scale is done on several carving craft galleries in Jepara involving a number of respondents. Respondents are gallery owners, customers who are visitors in the gallery, as well as input from experts of wood art crafts. The author uses a carved diameter of $40 \mathrm{~cm}$ without using a circular frame that has a side width of the outer $20 \mathrm{~cm}$ engraved plane. Because of the artwork, the approach used to know the advantages and disadvantages of the work. To know the quality of design Whether the carving is in accordance with predetermined criteria, the authors use a questionnaire that is distributed to customers who are more of a tentative and supportive reading.

The author has set the quality indicator by involving the elements of consideration that is the pleasure of desire, the pleasure of buying, the pleasure of the object itself, the pleasure of use, and the pleasure with respect to the other. The number of respondents representing the gallery owner is approximately 2-3 people, the respondents representing the visitors are approximately 5- 20 people, and the respondents representing the expert of craft art is 1-2 people. Trial in this stage is the search for public recognition that can not be objectified in absolute or absolute. Therefore, in order to approach objectivity, the judgment of the representation of the three principals is necessary to be proportionate.

This large-scale trial is conducted by asking the opinion of visitors to the carving craft gallery in Jepara and art exhibition visitors. Craft galleries are shops selling various carvings in Jepara. Visitors to the gallery will be consulted about Mantingan work. Respondents are shop owners or kiosks or direct buyers who become customers. Their interest to own or purchase products is done by data collection techniques through questionnaires so that the quantitative data obtained can support or support the qualitative data that has been done on User Interviews and Stakeholder Interviews.

In order to seek input inputs from a wider scale, the strategic steps taken to capture consumer opinions is to include the Mantingan Engraving Works at the exhibition that has been held by the Department of Fine Arts Unnes. The exhibition was held on 7-11 October 2016 at Gallery B9 Art University of Semarang, which is themed Potency of Art and Design in Building Creative Economy. The visitors of the exhibition are academicians at Semarang State University and Semarang City Community.

Table 1:-Result of Consumer Response to Innovative Carving Handicraft through Mantingan Ornamental Variety

\begin{tabular}{|c|c|c|c|c|c|}
\hline \multirow{2}{*}{$\begin{array}{l}\text { Dimension Aspects of Consumer Response Against } \\
\text { Innovative Carving Handicraft Through Variety of } \\
\text { Mantingan }\end{array}$} & \multicolumn{5}{|c|}{ Score in procentage } \\
\hline & 5 & 4 & 3 & 2 & 1 \\
\hline $\begin{array}{l}\text { Innovative Carving Craft Principles Through } \\
\text { Decoration Variety of Mantingan }\end{array}$ & & & & & \\
\hline $\begin{array}{l}\text { The uniqueness of the craft that use decorative } \\
\text { motifs in the showroom }\end{array}$ & 73 & 17 & 8 & 2 & 0 \\
\hline Practicality of a craft if functioned as decoration & 30 & 6 & 26 & 2 & 0 \\
\hline Jepara Identity Character or regionalism in the new & 82 & 9 & 4 & 2 & 3 \\
\hline
\end{tabular}




\begin{tabular}{|c|c|c|c|c|c|c|}
\hline & form & & & & & \\
\hline & $\begin{array}{l}\text { Design craft that is newer and different with } \\
\text { previous }\end{array}$ & 34 & 49 & 12 & 2 & 3 \\
\hline \multirow[t]{7}{*}{2} & $\begin{array}{l}\text { Aesthetics of Innovative Carving Craft through } \\
\text { Decorative Variety of Mantingan }\end{array}$ & 7 & & & & \\
\hline & Quality of Materials used for Handicrafts & 95 & 2 & 2 & 1 & 0 \\
\hline & Finishing model & 87 & 4 & 3 & 2 & 4 \\
\hline & The use of color is limited to craft & 76 & 18 & 3 & 2 & 1 \\
\hline & Decorative variety in handicraft & 45 & 45 & 6 & 2 & 2 \\
\hline & $\begin{array}{l}\text { Harmony between decorative with the structure of } \\
\text { craft form }\end{array}$ & 45 & 42 & 9 & 2 & 2 \\
\hline & $\begin{array}{l}\text { The composition of decoration that applied to the } \\
\text { craft }\end{array}$ & 78 & 18 & 4 & 0 & 0 \\
\hline
\end{tabular}

Based on the questionnaire results, most respondents stated that Mantingan decoration variety has been modified vertically, horizontally, and geographically innovation so as to produce a unique and beautiful carving craft. The survey was conducted in order to understand the aesthetic quality of carving craft that has been successfully created. The quality of Mantingan sculpture works includes unique crafts that use decorative motifs, the practicality of a craft if functioned as decoration, identity character of Jepara or regional in the new form, craft design is newer and different from before. From the survey results showed that respondents appreciate all the aspects that are asked by giving an average rating above $70 \%$ for the best score category. The respondents also had a very positive response about the Aesthetics of Innovative Carving Handicraft through the Variety of Mantingan. The average value of the respondents' assessment is $75 \%$. Aesthetic qualities of Mantingan handicraft include quality of materials used for craft, finishing model, limited use of color in handicraft, decoration in handicraft, harmony between decoration and craft form structure, and decorative composition applied to craft. The excellence of this carving art is to combine the traditional form with the icon of today is a Jepara carving of realistic leaves.

\section{Product Evaluation:-}

Experts with the competence of sculpture have argued that Mantingan sculpture designs have demonstrated design traits that have adapted to the desire of modern or contemporary living with the criteria of production efficiency and design, the expression of local identity, innovation and market potential, and the final appearance and worthy of production and sale in order to enrich alternative designs sold in Jepara carving centers. The idea of improvement of the expert is the affirmation of anatomical structure forms of plant parts including, flower petals, leaves, and stems in order to more realistic and authoritative expression.

\section{Mantingan Craft Products: Characteristics of Creative Motives:-}

The result of handicraft product successfully realized is carving craft which is categorized as decoration object, and not use object. The main purpose of making artworks interior decoration Mantingan to enjoy its beauty alone without any practical function. The work of this craft also implies the meaning as an impact of the author's expression so as to give a deeper impression to the appreciator when deepened.The types of motifs embodied in Mantingan ornaments include the motifs of flora and fauna. The motif of plants is the shape of the lotus plant distilled from the original with the aim of generating more carved characters of the present and the resulting forms of harmonious motifs. While the motif of ornamental animals is a bird motif that the description also use the stylization method to get a more beautiful shape. 


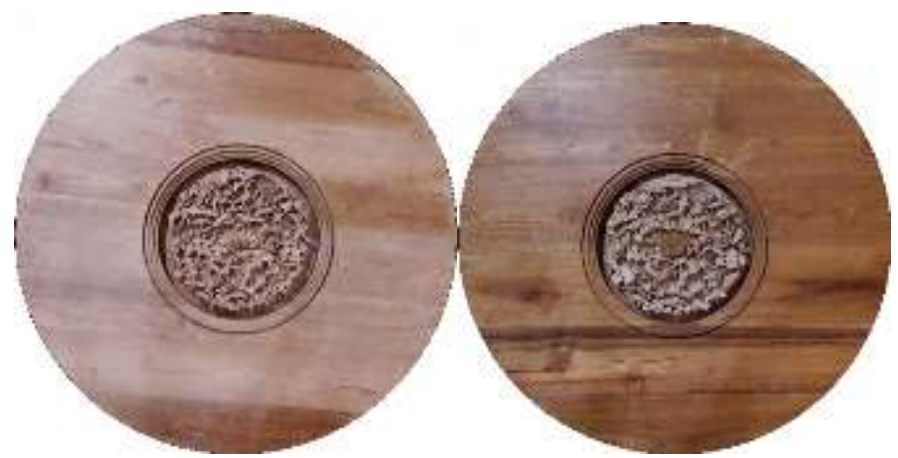

Fig. 4:- Stages of finishing performed on Mantingan engraving is through four measures of giving wood filler, wood stain, sending sealer, and top coat

The realization form of Mantingan sculpture have aesthetic value of the blend of various elements such by applying the principles of balance, harmony, unity, a point of interest, rhythm, and expression of the theme (GIE, 1976).

Table 2:- Matrix of Aesthetic Values In Mantingan Art Works

\begin{tabular}{|c|c|c|}
\hline \multicolumn{2}{|l|}{ Aspect } & Description \\
\hline \multirow{4}{*}{$\begin{array}{l}\text { Shape } \\
\text { aesthetics } \\
\text { (visual } \\
\text { elements) }\end{array}$} & Line & Lines are formed imaginary for the formation of carving motifs \\
\hline & Field & $\begin{array}{l}\text { Fields are formed significantly due to the formation of motifs of } \\
\text { carving. The forms that are created are biomorphic fields. In the } \\
\text { field of backkground formed geometric field }\end{array}$ \\
\hline & Texture & Most of the surface is fine textured \\
\hline & Dark light & $\begin{array}{l}\text { Dark light appears due to the convex and concave carvings. It is } \\
\text { more prominent when the lighting is turned on. }\end{array}$ \\
\hline \multirow{5}{*}{$\begin{array}{l}\text { Aesthetics } \\
\text { (visual } \\
\text { principles) }\end{array}$} & Balance & The balance is more symmetrical. \\
\hline & Harmony & $\begin{array}{l}\text { Harmony arises because the various forms of motif, color, texture, } \\
\text { darkness are harmoniously integrated }\end{array}$ \\
\hline & Rhytme & The rhythm is more visible in the decorative art of carving \\
\hline & $\begin{array}{l}\text { Center of } \\
\text { attention }\end{array}$ & $\begin{array}{l}\text { The balance can be seen in the ornamental art of carving that is in } \\
\text { the middle of the engraving field }\end{array}$ \\
\hline & Unity & $\begin{array}{l}\text { Unity is created because of various forms of motifs, colors, textures, } \\
\text { dark lights are harmoniously integrated and unified }\end{array}$ \\
\hline \multirow{3}{*}{ Reflektion } & Identity & Identity arises in the sculpture of Mantingan \\
\hline & Up to date & $\begin{array}{l}\text { Contemporary because of the inclusion of decorative ornaments } \\
\text { taken to be applied to the art of carving }\end{array}$ \\
\hline & Novelty & $\begin{array}{l}\text { The novelty of courage taking motive to be combined with the } \\
\text { original carving motif of Jepara, or other motives }\end{array}$ \\
\hline
\end{tabular}

\section{Conclusion:-}

The results showed the following. First, the design of Jepara carving art has been regional identity but less visualized in the style of contemporary and there is no craftsman who raises Mantingan style as an alternative new design in Jepara. The inheritance system of intergenerative carving ability is still done in family pattern and informally, especially during the process of carving work in studio or production place. Second, the concept of innovation developed by researchers in order to produce unique, quality, and contemporary carvings through the use of ornamental subject matter Mantingan is vertical innovation, horizontal innovation, and geographical innovation. Third, in this research has produced 3 pieces of interior wall decoration design through the application of Mantingan ornamentic style through ornamentical Islamic figurative and figurative disguised in contemporary style. The present impression arises because of the interwoven visual interplanation of Mantingan both internally and externally while still pursuing symbolic values as well as beautiful formalistic expressions and compositions. 
Suggestions that can be proposed are two-dimensional prototype and 3 dimensions need to be socialized to centers Jepara craft production so that its existence can improve the welfare of the community.

\section{References:-}

1. Arnheim, Rudolf, 1974. Art and Visual Perception, Edisi ke Dua, University of California Press, California

2. Avonsen, Joseph. 1970. The Encyclopedia of Furniture. London: B.T.Batsford

3. Collingwood, R.G., 1972. The Principles of Art, Oxford University Press, London, Oxford, New York,

4. De Bono, Edward. 1995. Serious Creativity: Using the Power of Lateral Thinking to Create New Ideas. London: Harpers Collins Publisher.

5. Gustami. 2000. Seni Kerajinan Mebel Ukir Jepara: Kajian Estetika Melalui Pendekatan Multidisiplin. Yogyakarta: Kanisius

6. Haryanto, Eko. 2012. "Strategi Pengembangan Desain Kria (Ragam Hias) dalam Perspektif Potensi Lokalitas: Studi Kasus Seni Ukir Jepara, Kuningan Pati, dan Batik Pekalongan” dalam Laporan Penelitian LP2M Unnes.

7. Ham, Ong Hok. 2002. Dari Soal Priyayi Sampai Nyi Blorong: Refleksi Historis Nusantara. Jakarta: Penerbit Buku Kompas.

8. Herusatoto, Budiono.2000. Simbolisme dalam Budaya Jawa. Yogyakarta: Hanindita.

9. Josepht Butler.1986. Field Guide To American Antigue Furniture. New York: Roundtable Press Book.

10. Koswara, Aji. 1996. Ukiran Jepara. Bandung: Tesis ITB

11. Koentjaraningrat. 1994. Kebudayaan Jawa. Jakarta: Balai Pustaka

12. Lombart, Denys. 2000. Nusa Jawa Silang Budaya, Bagian Satu: Batas-batas Pembaratan. Jakarta: Gramedia Pustaka Utama

13. Milles, Matthew B \& A. Michael Huberman. 1992. Analisis Data Kualitatif. Terjemahan Tjetjep Rohendi Rohidi, Jakarta: UI Press.

14. Prasetyowibowo, Bagas. 2000. Manajemen Desain. Bandung.

15. Read, Herbert. 1956. Art and Industry. London: Faber and Faber Ltd, h.40

16. Ridjan, Muchsin. 2013. "Ciptakan kerajinan Tangan Bernilai Ekonomi” dalam Kompas, 25 April 2013.

17. Rohidi, T.R. 2000. Kesenian dalam Pendekatan Kebudayaan. Bandung : STISI.

18. Sachari, Agus. 1986. Paradigma Desain Indonesia, CV Rajawali, Jakarta.

19. 2005. Metodologi Penelitian Budaya Rupa. Jakarta: Erlangga.

20. Soedarmono, R.M, Prof. Dr. 1995. Seni Dan Pariwisata, Makalah dalam Kongres Kesenian Indonesia I, Jakarta.

21. Soedarso, Sp, 2006, Trilogi Seni: Penciptaan Eksistensi dan Kegunaan Seni, Yogyakarta: Badan Penerbit ISI

22. Soetopo, H.B., 1996, Metodologi Penelitian Kualitatif, Universitas Sebelas Maret Surakarta.

23. Sugiyono.2011. Metode penelitian Kuantitatif Kualitatif dan R\&D.Bandung: Alfabeta.

24. Sukijo, Sudarmono. 1979. Pengetahuan Teknologi Kerajinan Ukir Kayu. Jakarta: Depdikbud

25. Solichin, Nanik S. 1975. "Tinjauan Seni Ornamen pada Bangunan Tradisional. Indonesia”. Skripsi. Bandung: ITB

26. Sunarya, I Ketut. 2003 "Seni, Motivasi Kehadirannya” dalam Ekspresi Jurnal Lembaga Penelitian ISI Yogyakarta. Vol. 7 Th.3

27. Sunaryo, Aryo. 2003. "Ragam Hias Fuguratif Masjid Mantingan Jepara". dalam Ekspresi Jurnal Lembaga Penelitian ISI Yogyakarta. Vol. 9 Tahun.2003

28. Sunarko, Keny. 1981. Mebel Kuno di Jawa. Bandung: Skripsi ITB

29. Suseno, Frans Magnis. 1996. Etika Jawa, sebuah Analisa Falsafi Tentang Kebijaksanaan Hidup. Jakarta: Gramedia

30. Sutjipto, Djoko. 1995. "Ragam Hias Tradisional dan Penerapannya dalam Desain”. Tesis Bandung: ITB

31. Triyanto.2012. "Seni Ukir Belakang Gunung Desa Mulyoharjo : Varian dalam Khazanah Tradisi Budaya Seni Ukir di Jepara". Laporan Penelitian Dasar. Jurusan Seni Rupa Fakultas Bahasa dan Seni Universitas Negeri Semarang.

32. Thohir, Mudjahirin. 1999. Wacana Masyarakat dan Kebudayaan Jawa Pesisir. Semarang: Bendera

33. Widagdo. 2006. "Penelitian Bidang Seni Rupa” dalam Jaringan Makna Tradisi Hingga Kontemporer. Yogyakarta: BP ISI

34. Zainuddin, Imam Buchori. (1986). Peranan Desain Dalam Peningkatan Mutu Produk, dalam Paradigma Desain Indonesia, Agus Sachari, Ed. CV Rajawali, Jakarta.

35. Kontan, 2012 "FurniturJepara Menggeliat dalam Lumpur Keterpurukan" dalam Kontan8-14 Oktober 2012, halaman 14).

36. Rusli, Iman. 2013. Memperkuat Identitas.Furnitur Asia Tenggara dalam Http://properti.kompas.com/read/2013/03/28/11265655/Memperkuat.Identitas.Furnitur.Asia.Tenggara(Kompas, 2014).s 